Marquette University

e-Publications@Marquette

Biomedical Sciences Faculty Research and

Publications

Biomedical Sciences, Department of

$1-1-2008$

Stressor- and Corticotropin releasing Factorinduced Reinstatement and Active Stress-related Behavioral Responses are Augmented Following Long-access Cocaine Self-administration by Rats

John R. Mantsch

Marquette University, john.mantsch@marquette.edu

David A. Baker

Marquette University, david.baker@marquette.edu

David M. Francis

Marquette University

Eric S. Katz

Marquette University

Michael A. Hoks

Marquette University

See next page for additional authors

Accepted version. Psychopharmacology, Vol. 195, No. 4 (January 2008): 591-603. The final publication is available at Springer: DOI. (C) 2008 Springer. Used with permission.

Shareable Link. Provided by the Springer Nature SharedIt content-sharing initiative. 
Authors

John R. Mantsch, David A. Baker, David M. Francis, Eric S. Katz, Michael A. Hoks, and Joseph P. Serge 


\title{
Stressor- and Corticotropin Releasing Factor-Induced Reinstatement and Active Stress- Related Behavioral Responses Are Augmented Following Long-Access Cocaine Self-Administration by Rats
}

\author{
John R. Mantsch \\ Department of Biomedical Sciences, Marquette University \\ Milwaukee, WI \\ David A. Baker \\ Department of Biomedical Sciences, Marquette University \\ Milwaukee, WI \\ David M. Francis \\ Department of Biomedical Sciences, Marquette University \\ Milwaukee, WI \\ Eric S. Katz \\ Department of Biomedical Sciences, Marquette University \\ Milwaukee, WI \\ Michael A. Hoks \\ Department of Biomedical Sciences, Marquette University \\ Milwaukee, WI
}




\title{
Joseph P. Serge \\ Department of Biomedical Sciences, Marquette University \\ Milwaukee, WI
}

\begin{abstract}
Rationale: Stressful events during periods of drug abstinence likely contribute to relapse in cocaine-dependent individuals. Excessive cocaine use may increase susceptibility to stressor-induced relapse through alterations in brain corticotropin-releasing factor (CRF) responsiveness.
\end{abstract}

Objectives: This study examined stressor- and CRF-induced cocaine seeking and other stress-related behaviors in rats with different histories of cocaine self-administration (SA).

Materials and methods: Rats self-administered cocaine under short-access (ShA; 2 h daily) or long-access (LgA; 6 h daily) conditions for 14 days or were provided access to saline and were tested for reinstatement by a stressor (electric footshock), cocaine or an icv injection of CRF and for behavioral responsiveness on the elevated plus maze, in a novel environment and in the light-dark box after a 14- to 17-day extinction/withdrawal period.

Results: LgA rats showed escalating patterns of cocaine SA and were more susceptible to reinstatement by cocaine, EFS, or icv CRF than ShA rats. Overall, cocaine SA increased activity in the center field of a novel environment, on the open arms of the elevated plus maze, and in the light compartment of a light-dark box. In most cases, the effects of cocaine SA were dependent on the pattern/amount of cocaine intake with statistically significant differences from saline self-administering controls only observed in LgA rats.

Conclusions: When examined after several weeks of extinction/withdrawal, cocaine SA promotes a more active pattern of behavior during times of stress that is associated with a heightened susceptibility to stressor-induced cocaine-seeking behavior and may be the consequence of augmented CRF regulation of addiction-related neurocircuitry.

Keywords: Addiction, Stress, Relapse, CRF, CRH, Reinstatement, Cocaine, Self-administration, Anxiety

Psychopharmacology, Vol. 194, No. 4 (January 2008): pg. 591-603. DOI. This article is @ Springer and permission has been granted for this version to appear in e-Publications@Marquette. Springer does not grant permission for this article to be further copied/distributed or hosted elsewhere without the express permission from Springer. 
NOT THE PUBLISHED VERSION; this is the author's final, peer-reviewed manuscript. The published version may be accessed by following the link in the citation at the bottom of the page.

\section{Introduction}

A growing body of evidence suggests that stress plays an important role in cocaine addiction (Sinha 2001). Anecdotal reports and correlative data (e.g., Najavits et al. 1998) suggesting that stressors promote cocaine use are supported by clinical laboratory findings that stress imagery can precipitate cocaine craving in recovering addicts (Sinha et al. 1999) and by preclinical studies demonstrating that stressors can reinstate extinguished cocaine seeking in rats (Erb et al. 1996; Ahmed and Koob 1997). In addition to findings that acute stressors promote drug use, it has been reported that stress-related behavioral responses emerge and/or are exaggerated as a consequence of prior cocaine exposure, suggesting that the relationship between stress and cocaine abuse represents a self-perpetuating cycle within which stress serves as both a precipitating factor for and a consequence of drug use. Although many of these stress-related responses are likely attributable to acute withdrawal and dissipate over time (Sarnyai et al. 1995; Mutschler and Miczek 1998; Basso et al. 1999), it is also possible that repeated cocaine use produces more longterm neuroadaptations that alter stressor-responsiveness in a way that promotes cocaine-seeking behavior.

One approach that has been used to investigate persistent druginduced neuroplasticity related to drug-seeking behavior has involved the study of rats provided chronic daily prolonged access to cocaine for SA. Rats provided long access to cocaine for SA each day (long access; LgA rats), but not rats provided shorter drug access (short access; ShA rats) display a progressive escalation of cocaine SA suggested to be related to the loss of control over drug use that is central to human cocaine addiction (Ahmed and Koob 1998). We and others have demonstrated that LgA rats also display greater reinstatement after administration of cocaine (Mantsch et al. 2004; Ahmed and Cador 2006) when measured several weeks after SA testing compared to rats self-administering under ShA conditions, suggesting that cocaine SA produces long-term neuroadaptations that lead to a heightened susceptibility to engage in cocaineseeking behavior and emerge in an intake-dependent manner. The first goal of the present study was to examine the influence of prior cocaine intake on stressor-induced

Psychopharmacology, Vol. 194, No. 4 (January 2008): pg. 591-603. DOI. This article is (C Springer and permission has been granted for this version to appear in e-Publications@Marquette. Springer does not grant permission for this article to be further copied/distributed or hosted elsewhere without the express permission from Springer. 
cocaine seeking, by comparing reinstatement by a stressor, uncontrollable electric footshock (EFS), between rats that previously self-administered cocaine under ShA and LgA conditions.

The neuropeptide corticotropin releasing factor (CRF) has been implicated in cocaine-seeking behavior (Sarnyai et al. 2001; Goeders and Guerin 2000). Central administration of CRF reinstates extinguished cocaine seeking (Erb et al. 2006b), while administration of CRF antagonists prevent reinstatement by EFS (Erb et al. 1998; Shaham et al. 1998; Lu et al. 2001). The sites of CRF action include the bed nucleus of the stria terminalis (BNST; Erb and Stewart 1999; Erb et al. 2001) and the ventral tegmental area (VTA; Wang et al. 2005, 2007) where CRF-induced increases in glutamate appear to activate mesocortical dopaminergic neurons, thus elevating dopamine (DA) in the medial prefrontal cortex (MPFC) and thereby stimulating corticostriatal glutamatergic projections into the nucleus accumbens (NAcc) core (Capriles et al. 2003; Sanchez et al. 2003; McFarland et al. 2004; Wang et al. 2005). Notably, CRF regulation of glutamate in the VTA and cocaine-seeking behavior emerges as a consequence of repeated cocaine administration (Wang et al. 2005). Thus, any intakedependent augmentation of EFS-induced reinstatement could be the consequence of enhanced CRF regulation of the mesocortical/corticostriatal pathway putatively involved in stressorinduced cocaine seeking. For this reason, the second goal of this study was to examine differences in reinstatement in response to a central CRF injection between ShA and LgA rats.

The final goal of this study was to determine if alterations in stressor-induced cocaine-seeking behavior were accompanied by altered responsiveness in other stress-related behavioral models. Although previous studies have demonstrated anxiety-like behavioral responses during early withdrawal from repeated cocaine administration (Sarnyai et al. 1995; Mutschler and Miczek 1998; Basso et al. 1999), very few studies (e.g., Erb et al. 2006a) have examined stress-related responses further into withdrawal, at times when many of the acute withdrawal symptoms have likely dissipated. The importance of examining such responses during late withdrawal is highlighted by the findings of Sorge and Stewart (2005), who demonstrated that stressor-induced reinstatement is lower during early withdrawal when "anxiety" responses are most pronounced and

Psychopharmacology, Vol. 194, No. 4 (January 2008): pg. 591-603. DOI. This article is (C Springer and permission has been granted for this version to appear in e-Publications@Marquette. Springer does not grant permission for this article to be further copied/distributed or hosted elsewhere without the express permission from Springer. 
is heightened later during withdrawal when "anxiety" responses are likely diminished. To investigate the relationship between stressorinduced drug seeking and other stress-related behavioral responses, we chose to also examine behavior within a novel environment and in the elevated plus maze and light/dark transition paradigms in ShA and LgA rats and saline self-administering (Sal) controls.

\section{Materials and methods}

One-hundred-thirty adult male Sprague-Dawley rats (Harlan Laboratories, St. Louis, MO, USA), approximately 90 days old ( $325 \mathrm{~g}$ ) were used for the study. Rats were housed individually in a temperature- and humidity-controlled, AAALAC-accredited animal facility under a $12 \mathrm{~h} / 12 \mathrm{~h}$ reversed light/dark cycle (lights on at 6:00 PM) and had access to food at all times, except when in the experimental chambers. Water was available at all times during the study, including in the experimental chambers. All procedures were carried out in accordance with the Guide for the Care and Use of Laboratory Animals as adopted and promulgated by the NIH.

\section{Catheterization surgery}

Rats were implanted with chronic indwelling catheters under ketamine $\mathrm{HCl}(100 \mathrm{mg} / \mathrm{kg}$, ip, Fort Dodge Animal Health, Fort Dodge, IA, USA) and xylazine (2 mg/kg, ip, Lloyd Laboratories, Shenandoah, IA, USA) anesthesia. A silicon-tubing catheter (Silastic $\AA$; Dow Corning, Midland, MI, USA; $0.64 \mathrm{~mm}$ i.d.; $1.19 \mathrm{~mm}$ o.d.) was inserted into the right posterior facial vein and down into the jugular vein so that it terminated at the right atrium. The catheter was sutured to the vein and continued subcutaneously to the animal's back where it exited $2 \mathrm{~cm}$ posterior to the scapula via a back-mounted 22-gauge guide cannula (Plastics One, Roanoke, VA, USA) attached using dental acrylic to a piece of polypropylene monofilament surgical mesh (Atrium Medical, Hudson, $\mathrm{NH}, \mathrm{USA}$ ) to permit connection of a polyethylene delivery line $(0.58 \mathrm{~mm}$ i.d. $\times 1.27 \mathrm{~mm}$ o.d.; Plastics One, Roanoke, VA, USA) encased in a stainless steel spring leash (Plastics One). The delivery line was connected to a 30-ml syringe in a motor-driven pump (Razel, Stamford, CT, USA) via a leak-proof fluid swivel (Instech Lab, Plymouth Meeting, PA, USA) suspended above the chamber to allow

Psychopharmacology, Vol. 194, No. 4 (January 2008): pg. 591-603. DOI. This article is @ Springer and permission has been granted for this version to appear in e-Publications@Marquette. Springer does not grant permission for this article to be further copied/distributed or hosted elsewhere without the express permission from Springer. 
drug delivery. The swivel and leash assembly was counter-balanced to permit relatively unrestrained movement. Rats were allowed to recover for at least 3 days before SA testing during which time they were provided acetaminophen $(480 \mathrm{mg} / \mathrm{l})$ in their drinking water. After implantation, rats were injected with a sterile cefazolin antibiotic solution (15 mg, iv; West-Ward Pharmaceutical, Eatontown, NJ, USA) each day. Catheters were filled daily with a heparin solution ( 83 i.u./ml) and capped whenever the leash/delivery line assembly was disconnected.

\section{SA apparatus}

Twenty operant conditioning chambers encased in sound attenuating cubicles (MED-Associates, St Albans, VT, USA) were used. One retractable lever and stimulus light were mounted on the front wall of the chamber. A second lever and light were located on the back wall. Exhaust fans in the cabinets provided ventilation and white noise to mask extraneous sound.

\section{SA training/testing}

After recovery from surgery, rats were trained to self-administer cocaine ( $1.0 \mathrm{mg} / \mathrm{kg} / \mathrm{inf}$, iv, NIDA, Bethesda, MD, USA) by pressing a lever under a FR1 schedule during daily 2-h sessions, within which the active (i.e., front) lever was extended into the chamber and the corresponding stimulus light was illuminated. Pressing the lever resulted in an iv infusion of drug or saline solution (200 $\mu$ l over $5 \mathrm{~s}$ ) followed by a 25-s time-out period during which the stimulus light was extinguished but the lever remained extended. Responding on a second, inactive (i.e., back) lever was recorded but had no programmed consequences. Once significant SA under the FR1 schedule was observed (i.e., >10 infusions), the response requirements for SA were increased to FR2 and then to FR4 using the same criterion. Once a stable response pattern was observed under the FR4 schedule (total responding $<10 \%$ variation from the mean over three consecutive sessions), rats were ready for SA testing.

Psychopharmacology, Vol. 194, No. 4 (January 2008): pg. 591-603. DOI. This article is (C Springer and permission has been granted for this version to appear in e-Publications@Marquette. Springer does not grant permission for this article to be further copied/distributed or hosted elsewhere without the express permission from Springer. 


\section{Experiment 1: cocaine and EFS induced reinstatement in $\operatorname{LgA}, \mathrm{ShA}$, and Sal rats}

Fifty-two total rats were used for this experiment. Once these rats met the criterion for acquisition, baseline SA was determined before assignment to one of two treatment groups according to the conditions under which cocaine was available for SA for the next 14 days. ShA rats $(n=18)$ continued to have access to cocaine for SA during daily 2 -h sessions. LgA rats $(n=18)$ were provided access to cocaine during daily $6-\mathrm{h}$ sessions across the 14 -day SA testing period. Sal rats $(n=16)$ were provided access to saline during daily $2-h$ sessions across the testing period. After 14 days of ShA or LgA SA, lever pressing was extinguished by replacing the cocaine solution with saline for 10 consecutive 2 -h extinction sessions. These sessions were otherwise identical to the ShA SA sessions. Sal control rats continued to have access to saline during this time. EFS and cocaine-induced reinstatement were examined during two consecutive sessions. EFSinduced reinstatement was examined during the first reinstatement session, before which rats received intermittent uncontrollable shocks though the stainless steel grid floors of the SA chambers for $10 \mathrm{~min}$. Shocks ( $0.5 \mathrm{~mA}, 0.5 \mathrm{~s}$ duration) were delivered an average of every $40 \mathrm{~s}$ (range 10-70) during the 10-min period within which the houselight was on, both response levers were retracted and the stimulus lights were extinguished. The reinstatement session was otherwise identical to extinction conditions. After testing for EFSinduced reinstatement, rats were tested for reinstatement by cocaine (10 mg/kg, ip) administered immediately before the subsequent 2-h session. Reinstatement was defined as responding on the previously reinforced lever and was compared to extinction day 10 . Responding on the inactive lever was also recorded during extinction and reinstatement.

\section{Experiment 2: CRF-induced reinstatement in $L g A, S h A$, and Sal rats}

\section{Lateral ventricular cannula implantation}

Fifty rats were used for this experiment (18 ShA, $16 \mathrm{LgA}$, and $16 \mathrm{Sal})$. At the time of catheterization, these rats were implanted

Psychopharmacology, Vol. 194, No. 4 (January 2008): pg. 591-603. DOI. This article is @ Springer and permission has been granted for this version to appear in e-Publications@Marquette. Springer does not grant permission for this article to be further copied/distributed or hosted elsewhere without the express permission from Springer. 
unilaterally with a guide cannula into the lateral ventricle. The tip of the $2.1-\mathrm{cm} 23$-gauge guide cannula was implanted $1 \mathrm{~mm}$ above the target injection site within the lateral ventricle using the following coordinates determined from Paxinos and Watson (1998): $a / p-1.0$ $\mathrm{mm}$ from bregma; $\mathrm{m} / \mathrm{l}+/-1.4 \mathrm{~mm}$ from midline; and $\mathrm{d} / \mathrm{v}-3.77 \mathrm{~mm}$ from dura. Injections were performed via a 2.2-cm 26- gauge microinjector, which extended $1-\mathrm{mm}$ below the tip of the guide when inserted. The implantation site alternated between the left and right lateral ventricle across subjects. Recovery times and postsurgical treatments were identical to those described above. The accuracy of cannula implantation was confirmed postmortem in each rat after cardiac perfusion with $60-\mathrm{ml} 0.9 \% \mathrm{NaCl}$ followed by $60-\mathrm{ml} 2.5 \%$ buffered neutral formalin under sodium pentobarbital anesthesia (55 $\mathrm{mg} / \mathrm{kg}$ ). After storage in $2.5 \%$ buffered neutral formalin for 7 days, $120-\mu \mathrm{m}$ sections were cut using a vibrotome, slide-mounted, and stained with cresyl violet for placement confirmation using a light microscope. Rats with injection sites outside of the lateral ventricle were excluded from the data analysis.

\section{Cocaine self-administration, extinction, and CRF-induced reinstatement}

After implantation, rats were trained to self-administer cocaine, as described above. Once stable response patterns were observed, rats were assigned to ShA, LgA, and Sal groups and were tested for 14 days as described for experiment 1 . Rats underwent extinction and CRF-induced reinstatement using procedures adapted from Erb et al. (2006b). After SA testing, responding was extinguished during four consecutive 2-h extinction sessions. Thereafter, rats received daily "sham" treatments before extinction sessions in which an injector was inserted into the guide with no infusion delivered. In contrast to experiment 1 , these sessions were $3 \mathrm{~h}$ long and continued until rats exhibited stable response patterns across three consecutive sessions (responding within $10 \%$ of the three-session mean) at which time reinstatement testing began. During reinstatement testing, rats received a $1-\mu$ infusion of CRF ( 0.5 or $1 \mu \mathrm{g}$; Sigma-Aldrich, St. Louis, MO, USA) or vehicle (sterile water) into the lateral ventricle over a 1min period approximately $10 \mathrm{~min}$ before placement into the chambers

Psychopharmacology, Vol. 194, No. 4 (January 2008): pg. 591-603. DOI. This article is (C Springer and permission has been granted for this version to appear in e-Publications@Marquette. Springer does not grant permission for this article to be further copied/distributed or hosted elsewhere without the express permission from Springer. 
NOT THE PUBLISHED VERSION; this is the author's final, peer-reviewed manuscript. The published version may be accessed by following the link in the citation at the bottom of the page.

for reinstatement testing during a 3-h session that was otherwise identical to sham conditions.

\section{Experiment 3: effects of cocaine self-administration on stress-related behavioral responses}

These experiments used 67 rats. The effects of SA on behavior within a novel environment and on the elevated plus maze were initially determined using 39 rats from experiment 1 (15 Sal, 13 ShA, and $11 \mathrm{LgA}$ ). These rats were tested for their novelty responses 1 day after testing for cocaine-induced reinstatement and then were tested on the elevated plus maze a day later. To further examine the effects of SA on anxiety-related behavioral responses, an additional 28 rats (10 ShA, $10 \mathrm{LgA}$, and $8 \mathrm{Sal}$ ) were added to the experiment. These rats went through SA and extinction and were not tested for reinstatement or responsiveness to novelty but instead were tested for behavior on the elevated plus maze 1 day after the final extinction session and for behavior in the light-dark box 1 day later. Twenty-four of these rats completed the SA and extinction phases of the experiment and underwent plus-maze and light/dark-box testing (9 LgA, 7 ShA, and 8 Sal).

\section{Behavioral responses within a novel environment}

Behavior within a novel environment was analyzed using an automated photocell system (Accuscan Instruments, Columbus, $\mathrm{OH}$, USA) consisting of $41 \times 41 \times 30 \mathrm{~cm}$ clear Plexiglas chambers with four sets of four sensors evenly spaced across the width and length of the chamber on two vertical planes ( 4.5 and $18.5 \mathrm{~cm}$ high) to permit measurement of horizontal and vertical activity. Total distance travelled (centimeter), distance travelled in the center of the chamber (when the rat was not within $1 \mathrm{~cm}$ of a wall), and time spent in the center of the chamber (seconds) were measured in 6-min bins and 30min blocks across a $1-\mathrm{h}$ period. Testing was conducted in an illuminated room 2-3 $\mathrm{h}$ into the active phase. The average light intensity in the centers of the test chambers was 288 Ix.

Psychopharmacology, Vol. 194, No. 4 (January 2008): pg. 591-603. DOI. This article is @ Springer and permission has been granted for this version to appear in e-Publications@Marquette. Springer does not grant permission for this article to be further copied/distributed or hosted elsewhere without the express permission from Springer. 
NOT THE PUBLISHED VERSION; this is the author's final, peer-reviewed manuscript. The published version may be accessed by following the link in the citation at the bottom of the page.

\section{Elevated plus maze}

A total of 63 rats were tested on the elevated plus maze ( 20 $\mathrm{ShA}, 20 \mathrm{LgA}$, and $23 \mathrm{Sal}$ ). The black polypropylene maze was elevated $72.4 \mathrm{~cm}$ from the ground with four $10.2-\mathrm{cm}$ wide $\times 50.8-\mathrm{cm}$ long runways (Med-Associates, St Albans, VT, USA). The two closed runways had $40.6 \mathrm{~cm}$ black polypropylene walls. The two open runways had $1.3-\mathrm{cm}$ high lips. To begin the test, rats were placed at the center of maze facing a closed arm. Plus-maze behavior was measured as the time spent on and numbers of explorations of and entries into the open arms of the maze during a 5-min session as determined by the average of counts recorded by an automated system and by an observer blind to the experimental treatment condition. For subjective rating, entries were recorded when a rat had four paws on an arm and explorations were recorded when a rat had two paws on an arm. Time spent on the open arms was defined as the sum of the intervals between open and closed arm entries. Testing on the elevated plus maze was conducted in an illuminated room $2-3 \mathrm{~h}$ into the active phase. The mean light intensities on the open and closed arms were 61.5 and $35.0 \mathrm{~lx}$, respectively.

\section{Light-dark box}

A total of 24 rats were tested in the light-dark box ( $7 \mathrm{ShA}, 9$ $\mathrm{LgA}$, and $8 \mathrm{Sal}$ ). The light-dark box consisted of a $94.0 \mathrm{~cm}$ long $\times 30.5$ $\mathrm{cm}$ wide $\times 15.2 \mathrm{~cm}$ high acrylic glass chamber divided into a $71.1 \mathrm{~cm}$ long $\times 30.5 \mathrm{~cm}$ wide light compartment with a white floor and walls and a transparent lid and a $22.9 \mathrm{~cm}$ long $\times 30.5 \mathrm{~cm}$ wide dark compartment with a black floor, walls, and a removable black lid. Movement between compartments was possible through a $10.2-\mathrm{cm}$ passageway. The chamber was located in a dim room with a high intensity light source directed at the light compartment resulting in a light intensity in that compartment of $85 \mathrm{Ix}$. Behavior in the light/dark box was analyzed using an observer blind to the experimental condition. At the beginning of the 10-min session, the rat was placed into the dark compartment facing one of the side walls. Time spent in and entries and explorations into the light and dark compartments and latency to enter the light compartment were measured. An entry was defined as introduction of all four paws into a compartment. An exploration was

Psychopharmacology, Vol. 194, No. 4 (January 2008): pg. 591-603. DOI. This article is @ Springer and permission has been granted for this version to appear in e-Publications@Marquette. Springer does not grant permission for this article to be further copied/distributed or hosted elsewhere without the express permission from Springer. 
NOT THE PUBLISHED VERSION; this is the author's final, peer-reviewed manuscript. The published version may be accessed by following the link in the citation at the bottom of the page.

defined as introduction of less than four paws into a compartment. Testing was conducted $2-3 \mathrm{~h}$ into the active phase.

\section{Statistical analysis}

The significance of between-group and within-group differences in SA and extinction between ShA, LgA, and Sal rats was determined using two-way SA condition $\times$ SA or extinction day ANOVA followed, when appropriate, by one-way ANOVA and two-tailed Dunnett tests for comparisons within groups with all comparisons to SA day 1 and Bonferroni-corrected t tests for comparisons across groups. EFS, cocaine, or CRF-induced reinstatement was examined using two-way $\mathrm{SA} \times$ reinstatement condition ANOVA followed by one-way ANOVA and post-hoc testing using Bonferroni-corrected t tests. A similar analysis was used to examine inactive lever responding. The significance of differences in behaviors on the elevated plus maze and in the light/dark box was determined using one-way ANOVA followed by post-hoc testing using Bonferroni-corrected t tests. Total distance travelled in and distance travelled in and time spent in the center area of novel environment were examined in 6-min time bins and 30-min time blocks and the significance of the effects of ShA, LgA, and Sal SA were determined using three-way ANOVA followed, when appropriate, by two-way and one-way ANOVA and post-hoc testing using Bonferroni-corrected t tests. The significance of differences in time spent in the center of the novelty test chamber was determined using one-way ANOVA followed by Bonferroni-corrected t tests.

\section{Results}

Cocaine SA and extinction for experiments 1 and 3 Because SA and extinction did not differ between the rats used for experiments 1 and 3, data for these rats were combined for statistical analysis and are shown in Fig. 1. Seventy of the 80 rats from these experiments completed SA and extinction testing ( $23 \mathrm{Sal}, 24 \mathrm{ShA}$, and $23 \mathrm{LgA}$ ). The remaining 10 rats were removed from the study because of catheter failure (eight rats) or illness (two rats). Two-way ANOVA showed significant main effects of SA condition $\left(F_{2,66}=440.78 ; P<0.001\right)$ and test day $\left(F_{13,858}=6.56 ; P<0.001\right)$ on $S A$ and a significant $S A$ condition $\times$ test day interaction $\left(F_{26,858}=5.03 ; P<0.001\right)$. Analysis of SA across

Psychopharmacology, Vol. 194, No. 4 (January 2008): pg. 591-603. DOI. This article is (C Springer and permission has been granted for this version to appear in e-Publications@Marquette. Springer does not grant permission for this article to be further copied/distributed or hosted elsewhere without the express permission from Springer. 
the 14-day test period within each group using one-way ANOVA showed that a progressive escalation occurred in $\mathrm{LgA}$, but not ShA or Sal, rats $\left(F_{13,351}=2.30 ; P<0.01\right)$ and reached statistical significance on days 12,13 , and 14 (Dunnett t test vs SA day $1 ; \mathrm{P}<0.05$ ). Two-way ANOVA showed significant effects of extinction day $\left(F_{9,603}=54.26\right)$ and SA group $\left(F_{2,67}=23.14\right)$ on extinction responding and a significant group $x$ day interaction $\left(F_{18,603}=11.76\right)$. As expected, extinction training significantly reduced responding in LgA and ShA rats (one-way repeated measures ANOVA; $\mathrm{P}<0.05$ ), but not Sal rats. Overall, responding during extinction was significantly lower in Sal rats compared to either ShA or LgA rats $(P<0.05)$. However, no significant differences in extinction responding were observed between ShA and $\mathrm{LgA}$ rats. To further examine differences in extinction responding among groups, we followed up our initial ANOVA with one-way ANOVA on each day of extinction. Significant differences among groups were found on each extinction day $(P<0.05)$. Post-hoc analyses showed that responding by ShA and LgA rats did not differ on any day of extinction but that responding by Sal rats was significantly lower than LgA rats on each extinction day and significantly lower than ShA rats on extinction days $1-7$ ( $P<0.05)$. Thus, although extinction training reduced responding in our LgA rats, responding in these rats remained higher than in Sal rats.

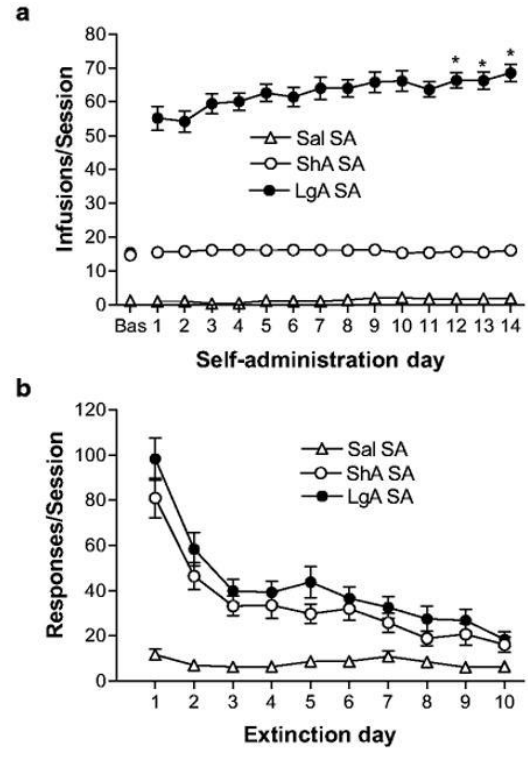

Fig. 1 Cocaine SA and extinction in ShA, LgA, and Sal rats from experiments 1 and 2 combined. Data in a represent the daily mean numbers of infusions selfadministered $( \pm \operatorname{SE})$ by ShA $(n=24), \operatorname{LgA}(n=23)$, and Sal $(n=23)$ rats across the 14-

Psychopharmacology, Vol. 194, No. 4 (January 2008): pg. 591-603. DOI. This article is (C Springer and permission has been granted for this version to appear in e-Publications@Marquette. Springer does not grant permission for this article to be further copied/distributed or hosted elsewhere without the express permission from Springer. 
NOT THE PUBLISHED VERSION; this is the author's final, peer-reviewed manuscript. The published version may be accessed by following the link in the citation at the bottom of the page.

day SA test period. Significant increases in SA compared to day 1 were found in LgA, but not ShA or Sal, rats (asterisk $P<0.05$ ). Data in $b$ represent the daily mean numbers of previously active lever presses ( $\pm \mathrm{SE}) \mathrm{ShA}$, LgA, and Sal rats during the 2$h$ extinction sessions across the 10-day extinction period. Differences in extinction responding were not observed between ShA and LgA rats.

\section{Experiment 1: EFS- and cocaine-induced reinstatement in $\operatorname{LgA}, \mathrm{ShA}$, and Sal rats}

\section{EFS-induced reinstatement}

EFS-induced reinstatement in Sal, ShA, and LgA rats is shown in Fig. 2. Fourteen $\operatorname{LgA}, 17 \mathrm{ShA}$, and 15 Sal rats were tested for reinstatement. Two-way ANOVA showed significant main effects of reinstatement condition (EFS vs Bas; $F_{1,43}=9.78 ; \mathrm{P}<0.01$ ) and $S A$ group $\left(F_{2,43}=11.80 ; P<0.001\right)$ on active lever responding and a significant group $\times$ reinstatement interaction $\left(F_{2,43}=5.92 ; P<0.01\right)$. Significant EFS-induced reinstatement was observed in $\operatorname{LgA}$, but not ShA, rats $(P<0.01)$ and EFS failed to increase responding in Sal rats or on the inactive lever. One-way ANOVA showed significant differences among groups in basal $\left(F_{2,45}=4.25 ; P<0.05\right)$ and $E F S$-induced $\left(F_{2,45}=11.15 ; P<0.001\right)$ responding. Under baseline conditions, responding did not significantly differ between ShA and LgA rats but was significantly higher in $\operatorname{LgA}$ rats than it was in Sal rats $(P<0.05)$. By contrast, responding after EFS was significantly higher in LgA rats than in ShA or Sal rats $(P<0.05)$.

Psychopharmacology, Vol. 194, No. 4 (January 2008): pg. 591-603. DOI. This article is (C) Springer and permission has been granted for this version to appear in e-Publications@Marquette. Springer does not grant permission for this article to be further copied/distributed or hosted elsewhere without the express permission from Springer. 


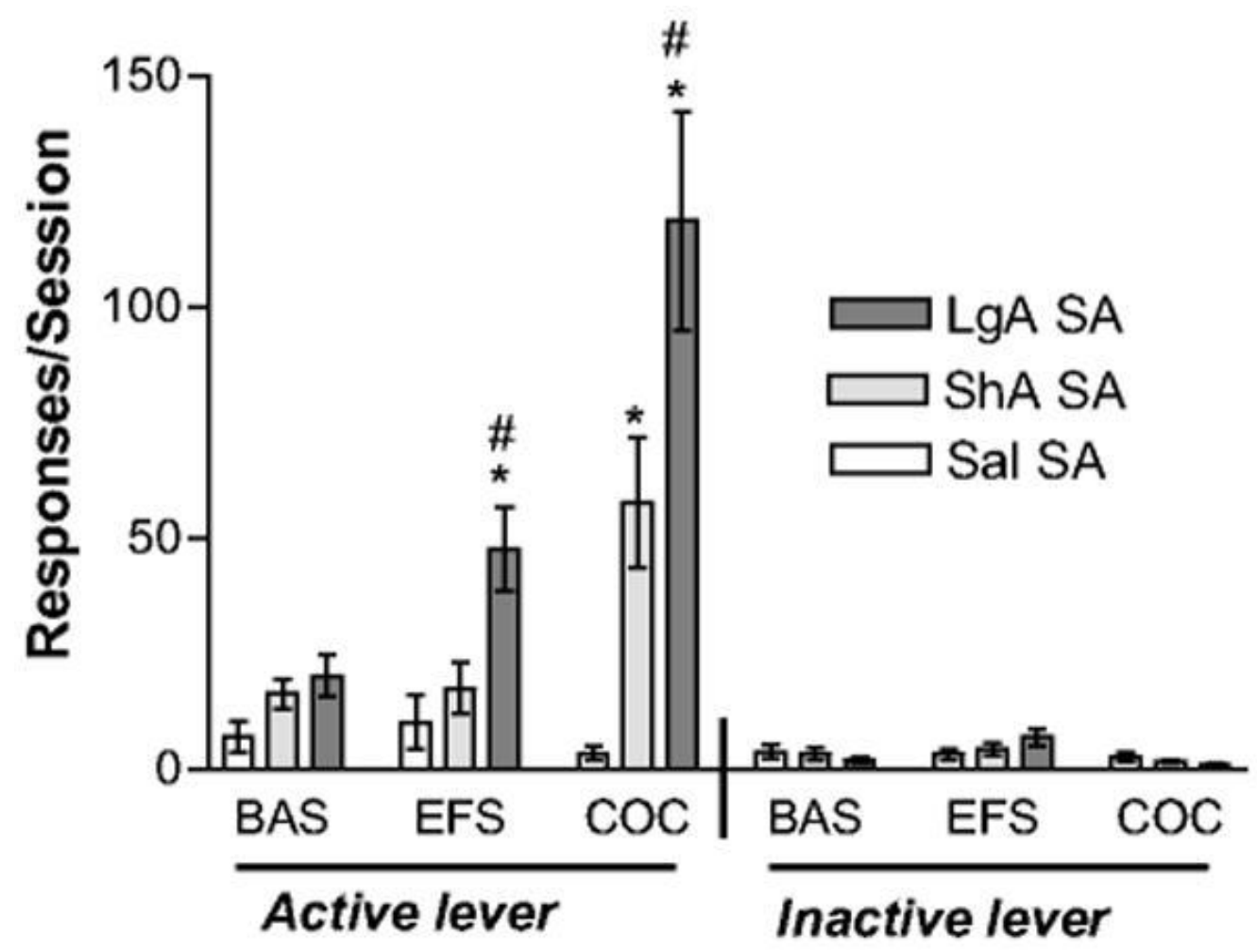

Fig. 2 EFS and cocaine-induced reinstatement in ShA, LgA, and Sal rats. Data represent previously active and inactive lever responding on the final day of extinction (BAS) and during the reinstatement sessions after exposure to EFS or administration of $10 \mathrm{mg} / \mathrm{kg}$ cocaine (ip; COC) in LgA $(n=14)$, ShA $(n=17)$, and Sal $(n=15)$ rats. EFS significantly increased active but not inactive lever pressing in LgA, but not ShA or Sal rats, while COC significantly increased active but not inactive lever pressing in LgA and ShA rats but not Sal rats (asterisk $\mathrm{P}<0.05$ vs Bas). Active lever pressing was significantly increased in LgA rats compared to ShA and Sal rats following EFS or COC administration (pound sign $\mathrm{P}<0.05$ vs ShA and Sal).

\section{Cocaine-induced reinstatement}

Because EFS failed to produce reinstatement in ShA rats, we tested all rats for reinstatement in response to cocaine $(10 \mathrm{mg} / \mathrm{kg}$, ip) to confirm that reinstatement could be observed (Fig. 2). Two-way ANOVA showed significant overall effects of reinstatement condition (Bas vs Coc; $\left.F_{1,43}=32.34 ; P<0.001\right)$ and $S A$ condition $\left(F_{2,43}=12.88\right.$; $\mathrm{P}<0.001)$ and a significant reinstatement $\times$ SA condition interaction $\left(F_{2,43}=12.98 ; P<0.001\right)$. Cocaine increased responding in ShA and $\mathrm{LgA}$, but not Sal rats $(P<0.05)$. One-way ANOVA revealed a significant main effect of SA group on cocaine-induced responding $\left(F_{2,45}=13.33\right.$; $\mathrm{P}<0.001)$. Post-hoc testing showed that cocaine-induced reinstatement 
was significantly higher in LgA rats than in ShA rats $(P<0.01)$. Cocaine-induced responding was increased in both ShA and LgA rats compared to Sal controls $(P<0.01)$.

\section{Experiment 2: CRF-induced reinstatement in $\operatorname{LgA}$, ShA, and Sal rats}

\section{SA and extinction}

Cocaine $\mathrm{SA}$ and extinction in rats tested for CRF-induced reinstatement are shown in Fig. 3. Forty-four rats (17 ShA, 13 LgA, and 14 Sal) completed and met the criterion for inclusion in the study. Three rats ( $1 \mathrm{LgA}$ and $2 \mathrm{Sal}$ ) were excluded because of inaccurate cannula placement. The remaining three rats ( $2 \mathrm{LgA}$ and $1 \mathrm{ShA}$ ) were removed because of catheter failure. Consistent with the results of experiments $1 / 3$, a progressive escalation of cocaine SA was observed in LgA but not ShA or Sal rats tested for later CRF-induced reinstatement. Twoway ANOVA showed significant effects of $S A$ condition $\left(F_{2,41}=395.06\right.$; $\mathrm{P}<0.001)$ and $\mathrm{SA}$ test day $\left(\mathrm{F}_{13,533}=8.21 ; \mathrm{P}<0.001\right)$ and a significant $\mathrm{SA}$ condition $\times$ test day interaction $\left(F_{26,533}=9.16 ; P<0.001\right)$. One-way ANOVA showed a significant main effect of SA test day in LgA but not ShA or Sal rats $\left(F_{13,182}=2.81 ; P<0.05\right)$. Post-hoc testing using a Dunnett t-test showed that cocaine SA was significantly increased compared to day 1 on days 8 and $10-14$ of SA testing in LgA rats $(P<0.05)$. Extinction responding did not differ between ShA and LgA rats but remained higher in ShA and LgA rats than in Sal controls $(P<0.05)$.

Psychopharmacology, Vol. 194, No. 4 (January 2008): pg. 591-603. DOI. This article is C Springer and permission has been granted for this version to appear in e-Publications@Marquette. Springer does not grant permission for this article to be further copied/distributed or hosted elsewhere without the express permission from Springer. 


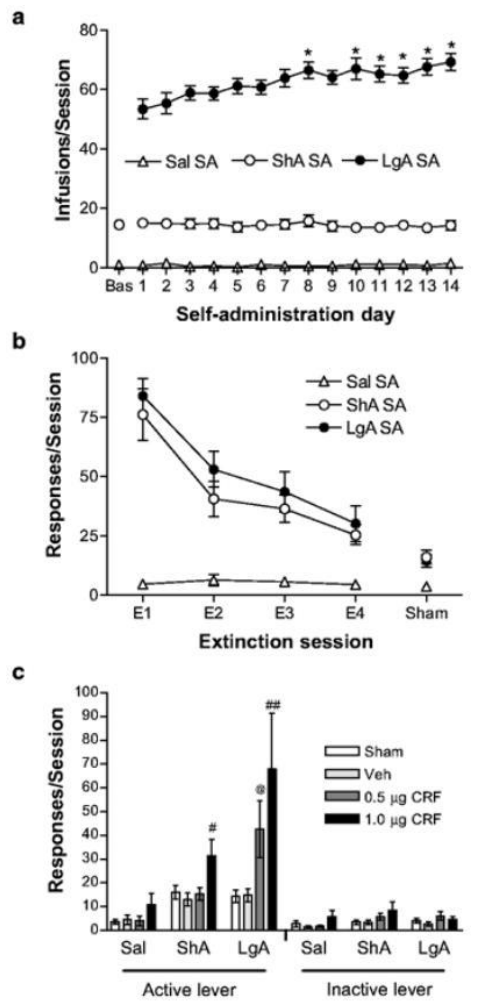

Fig. 3 Cocaine SA, extinction, and CRF-induced reinstatement in ShA, LgA, and Sal rats. Data in a represent the daily mean numbers of infusions self-administered ( $\pm \mathrm{SE})$ by ShA ( $n=17), \operatorname{LgA}(n=13)$, and Sal $(n=14)$ rats across the 14-day SA test period. Significant increases in SA compared to day 1 were found in LgA, but not ShA or Sal, rats (asterisk $\mathrm{P}<0.05$ ). Data in $\mathrm{b}$ represent the daily mean numbers of previously active lever presses $( \pm \mathrm{SE}) \mathrm{ShA}, \mathrm{LgA}$, and Sal rats during the initial four 2-h extinction sessions and the final 3-h icv sham session before reinstatement testing. Data in c represent previously active and inactive lever responding during the reinstatement sessions after an icv sham injection or icv injection of veh or 0.5 or $1.0 \mu \mathrm{g}$ CRF. $1.0 \mu \mathrm{g}$ CRF increased previously active lever pressing in ShA rats compared to veh conditions (pound sign $\mathrm{P}<0.05$ vs veh) and in LgA rats compared to sham conditions and veh pretreatment (double pound sign $\mathrm{P}<0.05$ vs sham and veh). Previously active lever responding following icv administration of $0.5 \mu \mathrm{g} C R F$ was significantly greater in LgA rats compared to ShA rats (at sign $\mathrm{P}<0.05$ vs ShA).

\section{CRF-induced reinstatement: active lever responding}

\section{Responding by Sal, ShA, and LgA rats during reinstatement} testing after central CRF administration is shown in Fig. 3. Two-way ANOVA showed significant overall effects of CRF treatment $\left(F_{2,82}=9.74\right.$; $\mathrm{P}<0.05)$ and $\mathrm{SA}$ condition $\left(\mathrm{F}_{2,41}=7.35 ; \mathrm{P}<0.05\right)$ on active lever responding and a significant $\mathrm{CRF} \times \mathrm{SA}$ condition interaction $\left(F_{4,82}=2.71 ; P<0.05\right)$. One-way ANOVA showed that significant $C R F-$

Psychopharmacology, Vol. 194, No. 4 (January 2008): pg. 591-603. DOI. This article is (C Springer and permission has been granted for this version to appear in e-Publications@Marquette. Springer does not grant permission for this article to be further copied/distributed or hosted elsewhere without the express permission from Springer. 
induced reinstatement was observed in both ShA $\left(F_{3,67}=3.94\right)$ and $\operatorname{LgA}$ $\left(F_{3,51}=3.64\right)$ rats, while no effects on previously active lever pressing were observed in Sal rats $\left(F_{3,55}=1.53\right)$. Post-hoc testing showed that the $1.0 \mu \mathrm{g}$ CRF dose significantly increased active lever pressing compared to vehicle in ShA rats and compared to both vehicle and sham treatment in LgA rats $(P<0.05)$. Despite a marked increase in active lever responding after $0.5 \mu \mathrm{g} C R F$ in $\mathrm{LgA}$ but not ShA rats, posthoc testing failed to show a significant increase compared to veh and sham treatment at this dose in LgA or ShA rats. Analysis of group effects under each CRF condition using one-way ANOVA showed significant effects of SA condition on active lever pressing after sham $\left(F_{2,43}=4.46\right)$, veh $\left(F_{2,43}=8.67\right)$, $0.5 \mu \mathrm{g} \operatorname{CRF}\left(F_{2,43}=4.38\right)$, or $1.0 \mu \mathrm{g} \mathrm{CRF}$ $\left(F_{2,43}=7.59\right)$ injections. In all cases, active lever responding was significantly higher in cocaine self-administering rats compared to Sal controls $(P<0.05)$. Additionally, at the $0.5 \mu \mathrm{g}$ CRF dose, active lever responding was significantly higher in $\mathrm{LgA}$ rats than ShA rats $(P<0.05)$. Differences between ShA and LgA rats were not observed at the 1.0- $\mu \mathrm{g}$ CRF dose or after veh or sham injections.

\section{CRF-induced reinstatement: inactive lever responding}

Two-way ANOVA also showed a significant overall effect of CRF treatment $\left(F_{3,123}=2.83\right)$ but not $S A$ condition on inactive lever responding with no significant CRF treatment $\times$ SA condition interaction. Post-hoc testing showed that, overall, inactive lever responding after administration of the 1.0- $\mu \mathrm{g}$ CRF dose was slightly but significantly higher than after veh $(P<0.05)$. However, significant increases in inactive lever responding compared to veh or sham treatment were not observed after administration of $0.5 \mu \mathrm{g}$ CRF. Further examination of CRF effects on inactive lever responding using one-way ANOVA failed to identify significant effects of CRF treatment in any individual SA group or differences across SA groups.

Psychopharmacology, Vol. 194, No. 4 (January 2008): pg. 591-603. DOI. This article is @ Springer and permission has been granted for this version to appear in e-Publications@Marquette. Springer does not grant permission for this article to be further copied/distributed or hosted elsewhere without the express permission from Springer 


\section{Experiment 3: effects of SA on stress-related behavioral responses}

\section{Novel environment}

The effects of SA on responsiveness to novelty were determined in 44 rats (15 Sal, 15 ShA, and $14 \mathrm{LgA}$ ) and are shown in Fig. 4. ANOVA failed to show significant SA group effects or interactions on total distance travelled in the test chamber (Fig. 3a). However, a significant interaction between SA condition, 30-min time block, and 6min time bin for distance travelled in the center of the chamber was found (Fig. 3b; F8,328=3.10; $\mathrm{P}<0.05$ ). Further analysis of center activity across the 6-min time bins in each of the 30-min blocks using two-way ANOVA showed significant SA condition $\times$ time-bin interactions during the first, but not second 30 min of testing $(F 8,164=2.47 ; P<0.05)$. Post-hoc testing showed that center activity during the first 30-min bin was increased in LgA rats compared to Sal but not ShA rats $(P<0.05)$. Significant differences were not found between ShA and Sal rats. One-way ANOVA after post-hoc testing only showed differences during the first 6-min bin during which center activity was increased in LgA rats compared to both Sal and ShA rats $(P<0.05)$. Time spent in the center of the chamber during the first and second time blocks is shown in Fig. 3c. Two-way ANOVA including both 30-min time blocks failed to show a significant overall effect of SA group or a significant SA group $\times$ time interaction. However, since significant effects on center activity were only observed during the first 30 min of testing, time spent in the center of the chamber was also examined during the first 30 min using one-way ANOVA, which showed a significant effect of SA group $(F 2,43=4.65 ; P<0.05)$. Time spent in the center was significantly higher in LgA rats than Sal, but not ShA rats $(P<0.05)$ and did not differ between Sal and ShA rats.

Psychopharmacology, Vol. 194, No. 4 (January 2008): pg. 591-603. DOI. This article is (C) Springer and permission has been granted for this version to appear in e-Publications@Marquette. Springer does not grant permission for this article to be further copied/distributed or hosted elsewhere without the express permission from Springer. 

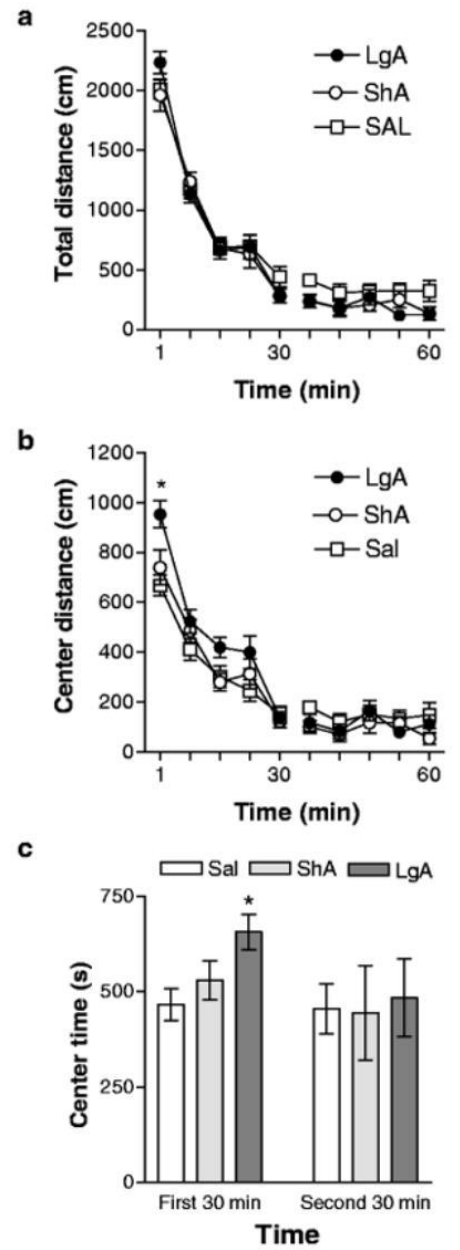

Fig. 4 Behavioral responsiveness within a novel environment in $\operatorname{ShA}(n=15), \operatorname{LgA}$ $(n=14)$, and Sal $(n=15)$ rats. Data represent the mean total distance travelled $(\mathrm{cm} \pm$ $\mathrm{SE} ; \mathrm{a})$ and the mean distance travelled in the center region of the testing chamber $(\mathrm{cm} \pm \mathrm{SE}$; b) measured in 6 -min time bins across the 1 -h session and the time spent in center region of the testing chamber during the first and second 30 min of testing ( $\mathrm{s}$ $\pm \mathrm{SE} ; \mathrm{c})$ measured 18-20 days after the final SA session in ShA, LgA, and Sal rats. Center distance travelled and time spent in the center but not total distance travelled were significantly increased in a time-dependent manner in $\mathrm{LgA}$, but not ShA rats, compared to Sal controls (Bonferroni-corrected t test; asterisk $\mathrm{P}<0.05 \mathrm{vs}$ Sal).

\section{Elevated plus maze}

Behavior on the elevated plus maze in Sal, ShA, and LgA rats is shown in Fig. 5. Because elevated plus maze behavior did not differ between rats that were tested for reinstatement and novelty responsiveness before plus maze testing and rats that were not, these rats were combined for analysis resulting in final sample sizes of 23 for 
Sal rats, 20 for ShA rats, and 20 for LgA rats. Surprisingly, rats in all three groups spent very little time on the open arms. One-way ANOVA revealed significant effects of SA condition on time-spent on the open arms $(F 2,62=4.84 ; \mathrm{P}<0.05)$ and the number of explorations of the open arms $(F 2,62=3.46)$ but not open arm entries, closed arm entries, or total entries. Post-hoc testing showed that time spent on the open arms was significantly increased in LgA rats compared to ShA rats $(P<0.05)$ but not Sal rats $(P=0.06)$ and that the number of explorations into the open arms was significantly greater in LgA rats than Sal $(P<0.05)$ but not ShA rats.

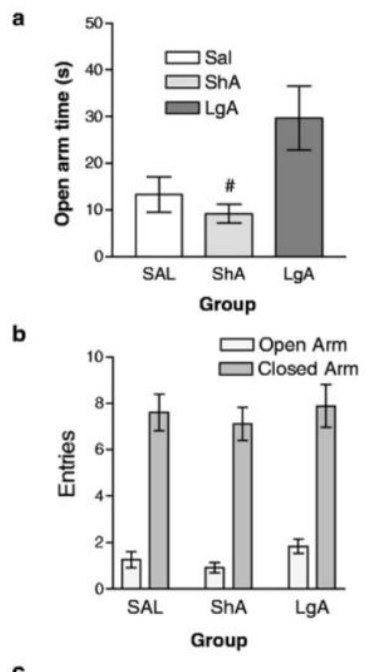

c

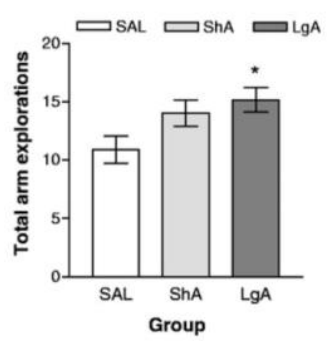

Fig. 5 Elevated plus-maze behavior in ShA $(n=20), \operatorname{LgA}(n=20)$ and Sal $(n=23)$ rats. Data represent mean time spent on the open arms of the elevated plus maze ( $\mathrm{s}$ $\pm \mathrm{SE} ; \mathrm{a})$, the mean numbers of open- and closed-arm entries ( $\pm \mathrm{SE} ; \mathrm{b})$, and the mean numbers of open-arm explorations ( $\pm \mathrm{SE}$; C) measured 18-20 days after the final SA session in ShA, LgA, and Sal rats. LgA rats spent significantly more time on the open arms of the plus maze than ShA rats (pound sign $\mathrm{P}<0.05$ vs ShA) and explored the open arms a significantly greater number of times than Sal rats (asterisk $P<0.05$ vs Sal). 
NOT THE PUBLISHED VERSION; this is the author's final, peer-reviewed manuscript. The published version may be accessed by following the link in the citation at the bottom of the page.

\section{Light/dark box}

Twenty-four rats ( 8 Sal, 7 ShA, and 9 LgA) were tested for behavior in the light/dark box. The numbers of entries into, latency to enter, and time spent in the light compartment in these rats are shown in Fig. 6. One-way ANOVA showed significant effects of SA group on light entries $(F 2,23=5.80 ; P<0.05)$, light explorations $(F 2,23=4.07$; $\mathrm{P}<0.05$; not shown), and latency to enter the light compartment $\mathrm{F} 2,23=3.49 ; \mathrm{P}<0.05)$, but not time spent in the light compartment $(F 2,23=3.02 ; P=0.07)$. Overall SA increased entries and explorations into and time spent in and reduced the latency to enter the light compartment. In all cases, post-hoc testing showed that responses differed between $\operatorname{LgA}$ and Sal rats $(P<0.05)$ but not $\mathrm{LgA}$ and ShA rats or Sal and ShA rats, suggesting that the observed effects emerged in an intak-dependent manner.

a
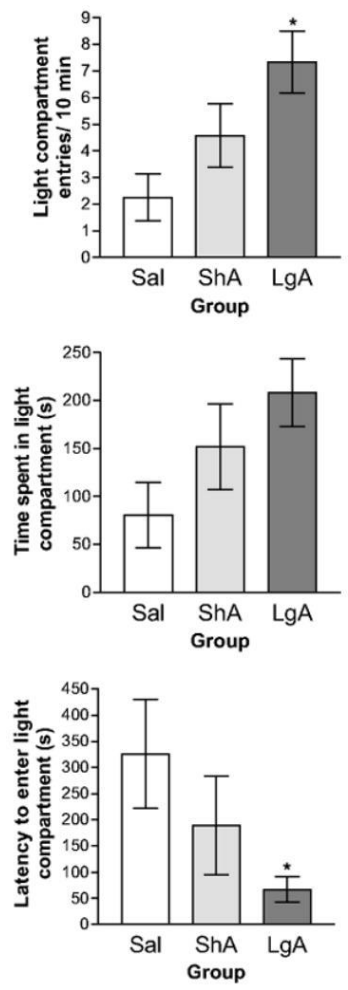

Fig. 6 Behavior in the light/dark box in ShA, LgA, and Sal rats. Data represent the number of entries into ( $\pm \mathrm{SE} ; \mathrm{a})$, the amount of time spent in ( $\pm \mathrm{SE} ; \mathrm{b})$, and the latency to enter ( $\mathrm{S} \pm \mathrm{SE} ; \mathrm{c}$ ) the light compartment of the light/dark box measured 1820 days after the final SA session in ShA $(n=7), \operatorname{LgA}(n=9)$, and Sal $(n=8)$ rats. The number of entries into the light compartment was significantly greater and the latency

Psychopharmacology, Vol. 194, No. 4 (January 2008): pg. 591-603. DOI. This article is (C) Springer and permission has been granted for this version to appear in e-Publications@Marquette. Springer does not grant permission for this article to be further copied/distributed or hosted elsewhere without the express permission from Springer. 
NOT THE PUBLISHED VERSION; this is the author's final, peer-reviewed manuscript. The published version may be accessed by following the link in the citation at the bottom of the page.

to enter the light compartment was significantly lower in LgA but not ShA rat compared to Sal controls (asterisk $\mathrm{P}<0.05$ vs Sal).

\section{Discussion}

Our findings confirm previous reports that rats selfadministering cocaine under LgA conditions display progressively escalating patterns of cocaine intake (Ahmed and Koob 1998; Mantsch et al. 2004) and demonstrate that escalated SA is associated with increased susceptibility to reinstatement by a stressor, uncontrollable EFS, when measured 2 weeks later. These findings are consistent with those of Ahmed et al. (2000) who showed that EFS-induced reinstatement of extinguished heroin-seeking behavior is also augmented as a consequence of SA under LgA conditions but differ from those of Sorge and Stewart (2005) who reported that rats selfadministering cocaine under LgA conditions were less susceptible to reinstatement by EFS than ShA rats during acute withdrawal, but that the magnitude of reinstatement intensified over time such that no differences were observed after 60 days.

Surprisingly, in our study, EFS only reinstated cocaine-seeking behavior in LgA rats. The lack of EFS-induced reinstatement in our ShA rats was unexpected considering that we and others (e.g., Erb et al. 1996; Ahmed and Koob 1997; Mantsch and Goeders 1999) have observed EFSSAL we were unable to observe significant EFS-induced reinstatement in ShA rats, we also tested the rats for reinstatement after a cocaine challenge. In contrast to EFS, cocaine-induced reinstatement was observed in both ShA and LgA rats. However, although a possible carryover effect of prior EFS-induced reinstatement cannot be ruled out, cocaine-induced reinstatement was significantly greater in LgA rats, as has been previously reported (Mantsch et al. 2004; Ahmed and Cador 2006; Mantsch et al. 2007). Together with reports by Kippen et al. (2006) that reinstatement by stimuli paired with cocaine SA is augmented in LgA rats, the findings suggest that susceptibility to drug relapse in response to stressors, drug re-exposure, or drug-paired cues is determined by the amount and/or pattern of prior SA. A role for CRF in stressor-induced reinstatement has been established. Central CRF administration reinstates extinguished cocaine seeking (Erb et al. 2006b) and CRF antagonists prevent reinstatement by EFS (Erb et al. 1998; Shaham et

Psychopharmacology, Vol. 194, No. 4 (January 2008): pg. 591-603. DOI. This article is (C Springer and permission has been granted for this version to appear in e-Publications@Marquette. Springer does not grant permission for this article to be further copied/distributed or hosted elsewhere without the express permission from Springer. 
al. 1998). The sites of CRF regulation of cocaine-seeking behavior appear to include a projection from the central amygdala into the BNST (Erb and Stewart 1999; Erb et al. 2001) and CRF projections into the VTA (Wang et al. 2005, 2007), presumably also from the amygdala. In the VTA, CRF appears to produce reinstatement by elevating extracellular glutamate through a mechanism that has been reported to involve association with its binding protein and activation of CRF-R2 receptors (Wang et al. 2007).

Application of CRF into the VTA results in excitation of both dopaminergic and GABAergic cells (Korotkova et al. 2006). CRF also facilitates glutamatergic regulation of DA neurons in the VTA by potentiation of NMDA receptor-mediated synaptic neurotransmission (Ungless et al. 2003). Stressor-induced regulation of cocaine seeking via CRF-dependent stimulation of DA neurons in the VTA likely involves downstream elevation of DA (Kalivas et al. 1987) and activation of DA receptors in the mPFC (Capriles et al. 2003; Sanchez et al. 2003; McFarland et al. 2004) and thereby stimulation of corticostriatal glutamatergic inputs into the NAcc core (McFarland et al. 2004). CRFinduced increases in extracellular DA in the NAcc have also been found (Kalivas et al. 1987).

Notably, it has been reported that EFS- and CRF-induced elevations of glutamate and DA in the VTA are only observed in rats with a prior history of cocaine exposure, while the extracellular CRF response to EFS in the VTA is unchanged (Wang et al. 2005), suggesting that CRF regulation of neurocircuitry underlying cocaineseeking behavior is established or augmented as a consequence of prior cocaine use, while the stressor-induced activity of CRF inputs into the VTA is not. Our finding that CRF-induced reinstatement is increased after LgA cocaine SA supports this possibility and is consistent with prior reports we were unable to observe significant EFS-induced reinstatement in ShA rats, we also tested the rats for reinstatement after a cocaine challenge. In contrast to EFS, cocaineinduced reinstatement was observed in both ShA and LgA rats. However, although a possible carryover effect of prior EFS-induced reinstatement cannot be ruled out, cocaine-induced reinstatement was significantly greater in LgA rats, as has been previously reported (Mantsch et al. 2004; Ahmed and Cador 2006; Mantsch et al. 2007). Together with reports by Kippen et al. (2006) that reinstatement by

Psychopharmacology, Vol. 194, No. 4 (January 2008): pg. 591-603. DOI. This article is (C Springer and permission has been granted for this version to appear in e-Publications@Marquette. Springer does not grant permission for this article to be further copied/distributed or hosted elsewhere without the express permission from Springer. 
stimuli paired with cocaine SA is augmented in LgA rats, the findings suggest that susceptibility to drug relapse in response to stressors, drug re-exposure, or drug-paired cues is determined by the amount and/or pattern of prior SA.

A role for CRF in stressor-induced reinstatement has been established. Central CRF administration reinstates extinguished cocaine seeking (Erb et al. 2006b) and CRF antagonists prevent reinstatement by EFS (Erb et al. 1998; Shaham et al. 1998). The sites of CRF regulation of cocaine-seeking behavior appear to include a projection from the central amygdala into the BNST (Erb and Stewart 1999; Erb et al. 2001) and CRF projections into the VTA (Wang et al. $2005,2007)$, presumably also from the amygdala. In the VTA, CRF appears to produce reinstatement by elevating extracellular glutamate through a mechanism that has been reported to involve association with its binding protein and activation of CRF-R2 receptors (Wang et al. 2007). Application of CRF into the VTA results in excitation of both dopaminergic and GABAergic cells (Korotkova et al. 2006). CRF also facilitates glutamatergic regulation of DA neurons in the VTA by potentiation of NMDA receptor-mediated synaptic neurotransmission (Ungless et al. 2003).

Stressor-induced regulation of cocaine seeking via CRFdependent stimulation of DA neurons in the VTA likely involves downstream elevation of DA (Kalivas et al. 1987) and activation of DA receptors in the mPFC (Capriles et al. 2003; Sanchez et al. 2003; McFarland et al. 2004) and thereby stimulation of corticostriatal glutamatergic inputs into the NAcc core (McFarland et al. 2004). CRFinduced increases in extracellular DA in the NAcc have also been found (Kalivas et al. 1987).

Notably, it has been reported that EFS- and CRF-induced elevations of glutamate and DA in the VTA are only observed in rats with a prior history of cocaine exposure, while the extracellular CRF response to EFS in the VTA is unchanged (Wang et al. 2005), suggesting that CRF regulation of neurocircuitry underlying cocaineseeking behavior is established or augmented as a consequence of prior cocaine use, while the stressor-induced activity of CRF inputs into the VTA is not. Our finding that CRF-induced reinstatement is increased after LgA cocaine SA supports this possibility and is

Psychopharmacology, Vol. 194, No. 4 (January 2008): pg. 591-603. DOI. This article is (C Springer and permission has been granted for this version to appear in e-Publications@Marquette. Springer does not grant permission for this article to be further copied/distributed or hosted elsewhere without the express permission from Springer. 
consistent with prior reports that the locomotor response to central CRF administration is sensitized as a result of prior cocaine exposure (Erb et al. 2003). These findings suggest that the emergent regulation of cocaine-seeking behavior by EFS in LgA rats may be the consequence of augmented CRF responsiveness within the VTA or other regions involved in EFS-induced reinstatement (e.g., the BNST) due in part to alterations in CRF receptors and/or downstream effectors within the VTA and/or mesocortical/corticostriatal pathway. Consistent with this possibility, an upregulation of CRF receptors in the VTA after repeated cocaine has been reported (Goeders et al. 1990). The effects of prior cocaine on stressor-induced neurochemical responses in the MPFC and NAcc are less clear, with an apparent reduction in the mPFC (Kalivas and Duffy 1989) and an augmentation of the NAcc (Sorg and Kalivas 1993) DA responses to EFS after repeated experimenter-delivered cocaine. Clarification of the relationship between altered responsiveness to $C R F$, neurochemical responses within the mesocorticolimbic system, and cocaine-seeking behavior will require further investigation in rats with a history of cocaine SA.

Although we hypothesize that augmented CRF-induced reinstatement was due to alterations in CRF-R2 activity, it is also possible that alterations in CRF-R1 receptors contributed to the effect. CRF-R1 antagonists have been reported to reduce cocaine SA (Goeders and Guerin 2000), cocaine-induced increases in NAcc DA (Lodge and Grace 2005), cocaine-induced conditioned place preference (Lu et al. 2003) and stressor- but not cocaine-induced reinstatement (Shaham et al. 1998; Lee et al. 2003).

Considering that CRF (Swanson et al. 1983) and its receptors (De Souza 1987) are expressed in number of brain regions implicated in cocaine-seeking behavior, it is also possible that alterations in CRF responsiveness outside of the VTA and BNST may have contributed to the observed increases in reinstatement. For example, it has been reported that prior cocaine exposure reduces CRF receptor binding (Goeders et al. 1990) augments CRF-induced c-fos mRNA expression (Erb et al. 2005) and promotes CRF-induced potentiation at glutamatergic synapses (Pollandt et al. 2006) in the CeA and alters CRF-R2 responsiveness in the lateral septum (Liu et al. 2005). Changes in CRF receptor binding have also been reported in the mPFC

Psychopharmacology, Vol. 194, No. 4 (January 2008): pg. 591-603. DOI. This article is (C Springer and permission has been granted for this version to appear in e-Publications@Marquette. Springer does not grant permission for this article to be further copied/distributed or hosted elsewhere without the express permission from Springer. 
and NAcc (Goeders et al. 1990). Notably, because many of these effects are observed during acute withdrawal, understanding their importance for cocaine seeking after more extended withdrawal periods will require further investigation.

To determine if the augmentation of stressor-induced reinstatement observed in LgA rats generalized to other stress-related behavioral responses, we tested Sal, ShA, and LgA rats for behavior in three separate procedures designed to examine active responses thought to be related to anxiety. Overall, cocaine SA increased open field but not total activity within a novel environment, time spent on the open arms of the elevated plus maze, and entries into the light compartment of the light-dark box. Notably, our findings, measured after a 14- to 17-day extinction/withdrawal period, tend to be directionally opposite from the effects reported during acute withdrawal which include reduced open-arm behavior on the plus maze (Sarnyai et al. 1995; Deroche-Gamonet et al. 2004), reduced light compartment entry in the light/dark box (Costall et al. 1990), heightened defensive burying behavior (Basso et al. 1999), and emission of distress-related ultrasonic vocalizations (Mutschler and Miczek 1998). Considering that increased open-arm behavior on the plus maze (Pellow et al. 1985) and increased transition into the light compartment in the light-dark box (Costall et al. 1989) are predictors of the anxiolytic properties of drugs, we were somewhat surprised that our LgA rats showed a behavioral response consistent with reduced anxiety, since EFS-induced reinstatement was augmented. A notable difference between the present study and previous studies examining anxiety-related behavioral responses after chronic cocaine exposure is that our rats were tested for these behaviors after a 10-day extinction training period after repeated cocaine SA. It has been reported that the neurobiological processes that underlie cocaine-seeking behavior after extinction are different from those that mediate cocaine seeking after drug abstinence (Sutton et al. 2003; Fuchs et al. 2006). Sutton et al. (2003) reported that extinction may have a particularly profound and long-lasting effect on stressor-induced cocaine seeking. Determination of the effects of extinction on anxiety-related behavioral responses following SA will require further investigation.

One interpretation of the present findings is that, with repeated cocaine use, behavioral responses to stressors are not attenuated but

Psychopharmacology, Vol. 194, No. 4 (January 2008): pg. 591-603. DOI. This article is (C Springer and permission has been granted for this version to appear in e-Publications@Marquette. Springer does not grant permission for this article to be further copied/distributed or hosted elsewhere without the express permission from Springer. 
are qualitatively different, such that a more active behavioral profile is displayed when confronted with a stressful situation, possibly because of engagement of neurocircuitry involved in motivation. We speculate that one consequence of this shift may be the establishment of a maladaptive coping strategy during periods of stress that includes an increased tendency to engage in cocaine-seeking behavior. This possibility is consistent with anecdotal reports that drug use becomes a viable strategy for coping with stress in addicted individuals and with findings that repeated cocaine administration reduces avoidance of a novel aversive stimulus in rats (Sorg et al. 2002). Alternatively, the findings may reflect an increased tendency of rats to engage in risktaking behavior, another hallmark of cocaine addiction (Vanderschuren and Everitt 2004).

Notably, there also seems to be a temporal dissociation between the "anxiogenic" effects of cocaine SA and stressor-induced cocaine seeking, both of which are CRF-dependent. During early withdrawal, rats display heightened behavioral signs of anxiety (Costall et al. 1990; Sarnyai et al. 1995; Mutschler and Miczek 1998; Basso et al. 1999), but EFS-induced reinstatement is relatively low (Sorge and Stewart 2005). By contrast, EFS-induced reinstatement is heightened later in withdrawal (Sorge and Stewart 2005) at times when many of the "anxiety" responses related to acute withdrawal are likely diminished. The role of regional changes in CRF actions in this apparent shift remains to be determined. In contrast to stressorinduced reinstatement which appears to involve CRF in the VTA and/or BNST, CRF in the central nucleus of the amygdala, which is markedly elevated during acute withdrawal (Richter and Weiss 1999; Zorrilla et al. 2001; Zhou et al. 2003), appears to underlie the anxiety associated with acute withdrawal (Sarnyai et al. 1995; Basso et al. 1999). Therefore, it is possible that distinct CRF systems subserving aversive vs appetitive functions are differentially regulated by repeated cocaine in a way that contributes to the temporally dynamic profile of stressor responsiveness during withdrawal.

\section{Conclusions}

In conclusion, our results indicate that excessive cocaine use alters stressor reactivity in a manner that promotes more active

Psychopharmacology, Vol. 194, No. 4 (January 2008): pg. 591-603. DOI. This article is (C Springer and permission has been granted for this version to appear in e-Publications@Marquette. Springer does not grant permission for this article to be further copied/distributed or hosted elsewhere without the express permission from Springer. 
behavioral responses. One consequence of this change in stressor responsiveness may be an increased tendency to use drugs during times of stress that is attributable to augmented regulation of addiction-related neurocircuitry by CRF. Overall, these findings support a role for stress in cocaine addiction and are consistent with reports that overall stressor responsiveness (Fox et al. 2007) and stressorinduced craving (Fox et al. 2005) are intensified in abstinent cocainedependent individuals in a manner that is dependent on the amount of prior use. Furthermore, our results suggest that pharmacotherapy aimed at attenuating the actions of CRF may be useful for preventing relapse in recovering cocaine addicts.

Acknowledgments: This work was supported by National Institute on Drug Abuse (NIDA) grant numbers DA15758 to JRM and DA17328 to DAB.

\section{References}

Ahmed SH, Cador M. Dissociation of psychomotor sensitization from compulsive cocaine consumption. Neuropsychopharmacology. $2006 ; 31: 563-571$.

Ahmed SH, Koob GF. Cocaine- but not food-seeking behavior is reinstated by stress after extinction. Psychopharmacology. 1997;132:289-295.

Ahmed SH, Koob GF. Transition from moderate to excessive drug intake: change in hedonic set point. Science. $1998 ; 282: 298-300$.

Ahmed SH, Walker JR, Koob GF. Persistent increase in the motivation to take heroin in rats with a history of drug escalation. Neuropsychopharmacology. 2000;22:413-421.

Basso AM, Spina M, Rivier J, Vale W, Koob GF. Corticotropin- releasing factor antagonist attenuates the "anxiogenic-like" effect in the defensive burying paradigm but not in the elevated plus-maze following chronic cocaine in rats. Psychopharmacology. 1999;145:21-30.

Capriles N, Rodaros D, Sorge RE, Stewart J. A role for the prefrontal cortex in stress- and cocaine-induced reinstatement of cocaine seeking in rats. Psychopharmacol. 2003;168:66-74.

Psychopharmacology, Vol. 194, No. 4 (January 2008): pg. 591-603. DOI. This article is (C Springer and permission has been granted for this version to appear in e-Publications@Marquette. Springer does not grant permission for this article to be further copied/distributed or hosted elsewhere without the express permission from Springer. 
NOT THE PUBLISHED VERSION; this is the author's final, peer-reviewed manuscript. The published version may be accessed by following the link in the citation at the bottom of the page.

Costall B, Jones BJ, Kelly ME, Naylor RJ, Tomkins Exploration of mice in the black and white test box: validation as a model of anxiety. Pharmacol Biochem Behav. 1989;32:777-785.

Costall B, Jones BJ, Kelly ME, Naylor RJ, Onaivi ES, Tyers MB. Ondansetron inhibits a behavioural consequence of withdrawing from drugs of abuse. Pharmacol Biochem Behav. 1990;36:339-344.

De Souza EB. Corticotropin-releasing factor receptors in the rat central nervous system: characterization and regional distribution. J Neurosci. $1987 ; 7: 88-100$.

Deroche-Gamonet V, Belin D, Piazza PV. Evidence for addiction-like behavior in the rat. Science. 2004;305:1014-1017.

Erb S, Stewart J. A role for the bed nucleus of the stria terminalis, but not the amygdala, in the effects of corticotropin-releasing factor on stressinduced reinstatement of cocaine seeking. J Neurosci. 1999;19:RC35.

Erb S, Shaham Y, Stewart J. Stress reinstates cocaine-seeking behavior after prolonged extinction and a drug-free period. Psychopharmacology. $1996 ; 128: 408-412$.

Erb S, Shaham Y, Stewart J. The role of corticotropin-releasing factor and corticosterone in stress- and cocaine-induced relapse to cocaine seeking in rats. J Neurosci. 1998;18:5529-5536.

Erb S, Salmaso N, Rodaros D, Stewart J. A role for the CRF-containing pathway from central nucleus of the amygdala to bed nucleus of the stria terminalis in the stress-induced reinstatement of cocaine seeking in rats. Psychopharmacology. 2001;158:360-365.

Erb S, Funk D, Le AD. Prior, repeated exposure to cocaine potentiates locomotor responsivity to central injections of corticotropin-releasing factor (CRF) in rats. Psychopharmacology. 2003;170:383-389.

Erb S, Funk D, Le AD. Cocaine pre-exposure enhances CRF-induced expression of c-fos mRNA in the central nucleus of the amygdala: an effect that parallels the effects of cocaine pre-exposure on CRFinduced locomotor activity. Neurosci Lett. 2005;383:209-214.

Erb S, Kayyali $\mathrm{H}$, Romero K. A study of the lasting effects of cocaine preexposure on anxiety-like behaviors under baseline conditions and in

Psychopharmacology, Vol. 194, No. 4 (January 2008): pg. 591-603. DOI. This article is @ Springer and permission has been granted for this version to appear in e-Publications@Marquette. Springer does not grant permission for this article to be further copied/distributed or hosted elsewhere without the express permission from Springer. 
NOT THE PUBLISHED VERSION; this is the author's final, peer-reviewed manuscript. The published version may be accessed by following the link in the citation at the bottom of the page.

response to central injections of corticotropin-releasing factor. Pharmacol Biochem Behav. 2006a;85:206-213.

Erb S, Petrovic A, Yi, Kayyali $\mathrm{H}$. Central injections of CRF reinstate cocaine seeking in rats after postinjection delays of up to $3 \mathrm{~h}$ : an influence of time and environmental context. Psychopharmacology. 2006b;187:112-120.

Fox HC, Talih M, Malison R, Anderson GM, Kreek MJ, Sinha R. Frequency of recent cocaine and alcohol use affects drug craving and associated responses to stress and drug-related cues. Psychoneuroendocrinology. $2005 ; 30: 880-891$.

Fox HC, Hong KI, Siedlarz K, Sinha R. Enhanced Emotional and Physiological Sensitivity to Stress and Drug/Alcohol Craving in Abstinent CocaineDependent Individuals Compared to Socially Drinking Controls. Neuropsychopharmacology. 2007 doi: 10.1038/sj.npp.1301426. in press.

Fuchs RA, Branham RK, See RE. Different neural substrates mediate cocaine seeking after abstinence versus extinction training: a critical role for the dorsolateral caudate-putamen. J Neurosci. 2006;26:3584-3588.

Goeders NE, Guerin GF. Effects of the CRH receptor antagonist CP-154,526 on intravenous cocaine self-administration in rats. Neuropsychopharmacology. 2000;23:577-586.

Goeders NE, Bienvenu OJ, De Souza EB. Chronic cocaine administration alters corticotropin-releasing factor receptors in the rat brain. Brain Res. $1990 ; 531: 322-328$.

Kalivas PW, Duffy P. Similar effect of daily cocaine and stress on mesocorticolimbic dopamine neurotransmission in the rats. Biol Psychiatry. 1989;25:913-928.

Kalivas PW, Duffy P, Latimer LG. Neurochemical and behavioral effects of corticotropin-releasing factor in the ventral tegmental area of the rat. J Pharmacol Exp Ther. 1987;242:757-763.

Kippin TE, Fuchs RA, See RE. Contributions of prolonged and non-contingent cocaine exposure to enhanced reinstatement of cocaine seeking in rats. Psychopharmacology. 2006;187:60-67.

Psychopharmacology, Vol. 194, No. 4 (January 2008): pg. 591-603. DOI. This article is @ Springer and permission has been granted for this version to appear in e-Publications@Marquette. Springer does not grant permission for this article to be further copied/distributed or hosted elsewhere without the express permission from Springer. 
NOT THE PUBLISHED VERSION; this is the author's final, peer-reviewed manuscript. The published version may be accessed by following the link in the citation at the bottom of the page.

Korotkova TM, Brown RE, Sergeeva OA, Ponomarenko AA, Haas HL. Effects of arousal- and feeding-related neuropeptide on dopaminergic and GABAergic neurons in the ventral tegmental area of the rat. Eur J Neurosci. 2006;23:2677-2685.

Lee B, Tiefenbacher S, Platt DM, Spealman RD. Role of the hypothalamic pituitary-adrenal axis in reinstatement of cocaine seeking in squirrel monkeys. Psychopharmacology. 2003;168:177-183.

Liu J, Yu B, Orozco-Cabal L, Grigoriadis DE, Rivier J, Vale WW, ShinnickGallagher P, Gallagher JP. Chronic cocaine administration switches corticotropin-releasing factor2 receptor-mediated depression to facilitation of glutamatergic transmission in the lateral septum. J Neurosci. 2005;25:577-583.

Lodge DJ, Grace AA. Acute and chronic corticotropin-releasing factor 1 receptor blockade inhibits cocaine-induced dopamine release: correlation with dopamine neuron activity. J Pharmacol Exp Ther. 2005;314:201-206.

Lu L, Liu D, Ceng X. Corticotropin-releasing factor receptor type 1 mediates stress-induced relapse to cocaine-conditioned place preference in rats. Eur J Pharmacol. 2001;415:203-208.

Lu L, Liu Z, Huang M, Zhang Z. Dopamine-dependent responses to cocaine depend on corticotropin-releasing factor receptor subtypes. J Neurochem. 2003;84:1378-1386.

Mantsch JR, Goeders NE. Ketoconazole blocks the stressor-induced reinstatement of cocaine-seeking behavior in rats: relationship to the discriminative stimulus effects of cocaine. Psychopharmacology. 1999;142:399-407.

Mantsch JR, Yuferov V, Mathieu-Kia A-M, Ho A, Kreek MJ. Effects of extended access to high versus low cocaine doses on self-administration, cocaine-induced reinstatement and brain mRNA levels in rats. Psychopharmacology. 2004;175:26-36.

Mantsch JR, Baker DA, Serge JP, Hoks MA, Francis DM, Katz ES. Surgical adrenalectomy and diurnal corticosterone replacement slow escalation and prevent augmented cocaine-induced reinstatement in rats selfadministering cocaine under long-access conditions.

Psychopharmacology, Vol. 194, No. 4 (January 2008): pg. 591-603. DOI. This article is @ Springer and permission has been granted for this version to appear in e-Publications@Marquette. Springer does not grant permission for this article to be further copied/distributed or hosted elsewhere without the express permission from Springer. 
NOT THE PUBLISHED VERSION; this is the author's final, peer-reviewed manuscript. The published version may be accessed by following the link in the citation at the bottom of the page.

Neuropsychopharmacology. 2007 doi: 10.1038/sj.npp.1301464. in press.

McFarland K, Davidge SB, Lapish CC, Kalivas PW. Limbic and motor circuitry underlying footshock-induced reinstatement of cocaine-seeking behavior. J Neurosci. 2004;24:1551-1560.

Mutschler $\mathrm{NH}$, Miczek KA. Withdrawal from iv cocaine binges in rats: ultrasonic distress calls and startle. Psychopharmacology. 1998;135:161-168.

Najavits LM, Gastfriend DR, Barber JP, Reif S, Muenz LR, Blaine J, Frank A, Crits-Christoph $P$, Thase M, Weiss RD. Cocaine dependence with and without PTSD among subjects in the National Institute on Drug Abuse Collaborative Cocaine Treatment Study. Am J Psychiatry. 1998; 155:214-219.

Paxinos G, Watson C. The Rat Brain in Stereotaxic Coordinates. 4. Academic; San Diego: 1998.

Pellow S, Chopin P, File SE, Briley M. Validation of open: closed arm entries in an elevated plus-maze as a measure of anxiety in the rat. J Neurosci Methods. $1985 ; 14: 149-167$.

Pollandt S, Liu J, Orozco-Cabal L, Grigoriadis DE, Vale WW, Gallagher JP, Shinnick-Gallagher P. Cocaine withdrawal enhance long-term potentiation induced by corticotropin-releasing factor at central amygdala glutamatergic synapses via CRF, NMDA receptors, and PKA. Eur J Neurosci. 2006;24:1733-1743.

Richter RM, Weiss F. In vivo CRF release in rat amygdala is increased during cocaine withdrawal in self-administering rats. Synapse. 1999;32:254261.

Sanchez CJ, Bailie TM, Wu WR, Li N, Sorg BA. Manipulation of dopamine D1like receptor activation in the rat medial prefrontal cortex alters stressand cocaine-induced reinstatement of conditioned place preference behavior. Neuroscience. 2003;119:497-505.

Sarnyai Z, Biro E, Gardi J, Vecsernyes M, Julesz J, Telegdy G. Brain corticotropin-releasing factor mediates 'anxiety-like' behavior induced by cocaine withdrawal in rats. Brain Res. 1995;675:89-97.

Psychopharmacology, Vol. 194, No. 4 (January 2008): pg. 591-603. DOI. This article is C Springer and permission has been granted for this version to appear in e-Publications@Marquette. Springer does not grant permission for this article to be further copied/distributed or hosted elsewhere without the express permission from Springer. 
NOT THE PUBLISHED VERSION; this is the author's final, peer-reviewed manuscript. The published version may be accessed by following the link in the citation at the bottom of the page.

Sarnyai Z, Shaham Y, Heinrichs SC. The role of corticotropin-releasing factor in drug addiction. Pharmacol Rev. 2001;53:209-43.

Shaham Y, Funk D, Erb S, Leung S, Buczek Y, Stewart J. CP-154,526, a selective, non-peptide antagonist of the corticotropin-releasing factor 1 receptor attenuates stress-induced relapse to drug seeking in cocaineand heroin-trained rats. Psychopharmacology. 1998;137:184-190.

Sinha R. How does stress increase risk of drug abuse and relapse? Psychopharmacology. 2001;158:343-359.

Sinha R, Catapano D, O'Malley S. Stress-induced craving and stress response in cocaine dependent individuals. Psychopharmacology. $1999 ; 142: 343-351$.

Sorg BA, Kalivas PW. Effects of cocaine and footshock stress on extracellular dopamine levels in the medial prefrontal cortex. Neuroscience. $1993 ; 53: 695-703$.

Sorg BA, Davidson DL, Hochstatter T, Sylvester PW. Repeated cocaine decreases the avoidance response to a novel aversive stimulus in rats. Psychopharmacology. 2002;163:9-19.

Sorge RE, Stewart J. The contribution of drug history and time since termination of drug taking to footshock stress-induced cocaine seeking in rats. Psychopharmacology. 2005;183:210-217.

Sutton MA, Schmidt EF, Choi KH, Schad CA, Whisler K, Simmons D, Karanian DA, Monteggia LM, Neve RL, Self DW. Extinction-induced upregulation in AMPA receptors reduces cocaine-seeking behavior. Nature. $2003 ; 421: 70-75$.

Swanson LW, Sawchenko PE, Rivier J, Vale WW. Organization of ovine corticotropin-releasing factor immunoreactive cells and fiber in the rat brain: an immunohistochemical study. Neuroendocrinology. $1983 ; 36: 165-186$

Ungless MA, Singh V, Crowder TL, Yaka R, Ron D, Bonci A. Corticotropinreleasing factor requires CRF binding protein to potentiate NMDA receptors via CRF receptor 2 in dopamine neurons. Neuron. 2003;39:401-407.

Psychopharmacology, Vol. 194, No. 4 (January 2008): pg. 591-603. DOI. This article is (C Springer and permission has been granted for this version to appear in e-Publications@Marquette. Springer does not grant permission for this article to be further copied/distributed or hosted elsewhere without the express permission from Springer. 
NOT THE PUBLISHED VERSION; this is the author's final, peer-reviewed manuscript. The published version may be accessed by following the link in the citation at the bottom of the page.

Vanderschuren LJMJ, Everitt BJ. Drug seeking becomes compulsive after prolonged cocaine self-administration. Science. 2004;305:1017-1019.

Wang B, Shaham Y, Zitzman D, Azari S, Wise RA, You ZB. Cocaine experience establishes control of midbrain glutamate and dopamine by corticotropin-releasing factor: a role in stressinduced relapse to drug seeking. J Neurosci. 2005;25:5389-5396.

Wang B, You ZB, Rice KC, Wise RA. Stress-induced relapse to cocaine seeking: roles for the $\operatorname{CRF}(2)$ receptor and CRF-binding protein in the ventral tegmental area of the rat. Psychopharmacology.

2007;193:283-294.

Zhou Y, Spangler R, Ho A, Kreek MJ. Increased CRH mRNA levels in the rat amygdala during short-term withdrawal from chronic 'binge' cocaine. Brain Res Mol Brain Res. 2003;114:73-79.

Zorrilla EP, Valdez GR, Weiss F. Changes in levels of regional CRF-likeimmunoreactivity and plasma corticosterone during protracted drug withdrawal in dependent rats. Psychopharmacology. 2001;158:374381.

\section{About the Authors}

Corresponding author: Department of Biomedical Sciences, Marquette University, Schroeder Health Complex, P.O. Box 1881, Milwaukee, WI 532011881, USA

John R. Mantsch: john.mantsch@marquette.edu

Psychopharmacology, Vol. 194, No. 4 (January 2008): pg. 591-603. DOI. This article is @ Springer and permission has been granted for this version to appear in e-Publications@Marquette. Springer does not grant permission for this article to be further copied/distributed or hosted elsewhere without the express permission from Springer. 